\title{
Mandor, for Solving Competitive Construction Business in Indonesia
}

\author{
Hary Agus Rahardjo and Henni Bermawi
}

\begin{abstract}
In the construction industry in Indonesia, building contractors are very much depend on mandor. The mandor is a person who also has capability to hire people to work together for a certain time, certain location and certain purpose at construction project. Mandor is not quite the same as foreman. In line with construction activities growth in urban area, demand for qualified building contractor is necessity. Building contractor is a company which has a contract to develop a building construction. Collaboration of best contractor and best mandor is the answer. The question is how to make the best mandor and best contractor.
\end{abstract}

Index Terms-Mandor, building contractor, construction.

\section{INTRODUCTION}

Construction activities in urban areas in Indonesia have seen rampant lately. Physical development such as homes, buildings, commercial building and other municipal infrastructure is the case, both by the government and private sectors. This situation happened related to economic development and the increase of urban population that occurred from year to year, as shown in fig. 1 below [1].

Population growth in urban areas is partly contributed by urbanization. Urbanization is happening because migrant people want a better life and facilities, which they can only meet in the urban area. This condition encourages increased physical development in urban areas that ultimately drive the growth of the construction industry. The construction sector is one of the main pillars of the national economic development. Developments affecting the construction sector not only to economic life, but also a positive impact on community social life. Social cohesion in society and economic progress can be awakened with a variety of actors working in the construction industry [2]. The building contractors, which have a contract to develop building construction, are taking an important role in the construction industry.

The problem is that the professionalism of building contractor's workforces is often inadequate. Mandor is one labor involved in building contractor activities. The role of mandor as contractor's labor is very significant. The question is how to increase the capacity of mandor to support the competitiveness of contractors in the construction industry in Indonesia?

Manuscript received April 10, 2013; revised June 10, 2013.

The authors are with the University of Persada Indonesia, Jakarta, Indonesia (e-mail: rahardjo30@yahoo.com; henn1_bm@yahoo.com).

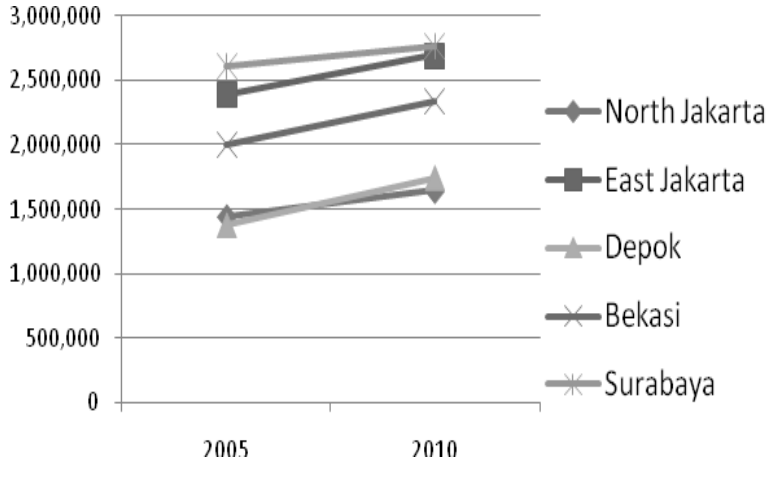

Fig. 1. Population growth in urban area

This research is intended to describe function, role and the importance of mandor as one of parties involved in the construction industry and how to develop mandor as part of supply chain system in contractor business. Managing mandor means change threats become opportunities in term of developing best quality of the construction project.

\section{RESEARCH METHOD}

Research method used in this paper is included the study of literature, primary data analysis and observations, also related secondary data processing. Secondary data analysis and studies is intended to get an overview of the factors related to construction activities, such as government regulations and existing laws, population growth and economy development in the Jakarta, Bogor, Depok, Tangerang and Bekasi (Jabodetabek) area. Observations made by looking directly at the field and interviews with mandor and building contractor.

\section{RESULT AND DISCUSSION}

Indonesia has been growing steadily at an impressive rate of 4 to 6 percent over the past 10 years -- less volatile than the economies of Brazil, Russia, India, and China, or any other developed country for that matter. Indonesian government debt has fallen by 70 percent in just a decade and is now at a level lower than in 85 percent of developed economies. Inflation, which was over 20 percent 10 years ago, now stands at 8 percent, comparable with more mature economies, such as South Africa and Turkey. Indonesia's overall economic management has also shown remarkable improvement. The World Economic Forum ranked Indonesia $25^{\text {th }}$ out of 139 countries for macroeconomic stability in 2012, up sharply from $89^{\text {th }}$ in 2007. For comparison, Brazil ranked $62^{\text {nd }}$ and India ranked $99^{\text {th }}[3]$. 
TABLE I: ECONOMIC AND CONSTRUCTION SECTOR GROWTH

\begin{tabular}{|l|l|l|l|l|l|l|}
\hline Year & 2007 & 2008 & 2009 & 2010 & 2011 & Average \\
\hline $\begin{array}{l}\text { Construction } \\
\text { Sector Growth }\end{array}$ & 8.53 & 7.55 & 7.70 & 6.95 & 6.71 & 7.49 \\
\hline $\begin{array}{l}\text { Economic } \\
\text { Growth }\end{array}$ & 6.35 & 6.01 & 4.58 & 6.10 & 6.50 & 5.91 \\
\hline
\end{tabular}

Source: Indonesia Statistic Bureau 2012

Volume of production for the annual construction sector activity ranged from 7 to $8 \%$ in 2011 and projected at 8.5 to $9.5 \%$ in year 2015 [1]. This indicates that the activities of the construction sector is very excited, as excited as production activities related to basic human needs such as food and beverages. This is in line with government policy that promotes the development of infrastructure as the locomotive of economic growth led to increased social welfare. Meanwhile, the public welfare move other economic activities, resulting in a multiplier effect on business activities conducted by private parties, including those engaged in construction. Table I below shows the economic and construction sector growth from 2007 to 2011 .

\section{A. Construction Project Management System}

Implementation of the development of construction projects in Indonesia are undertaken by various parties. Parties directly involved in the development activity are the owner, consultant planners, contractors and construction management consultant. Owner is obliged to provide funding for the establishment aspects of the project. Planner Consultant is responsible for the manufacture of technical project plan, including detailed engineering design. Contractor shall carry out projects development. While supervising the implementation of project development is undertaken by Consultant for construction management. These four parties are the core team in the implementation of project development. In addition to the core team, other parties are also involved such as the fund raiser, when the owner's financial capability is not sufficient. Building material needs are met by the supplier. Surrounding communities and communities in general being act as supporters and users of the project later after it was completed. The role of government which is also involved in this development is to function as a regulator, so that the projects are built with good and useful to users [4]. The Fig. 2 shows the core team and others involved in a construction project.

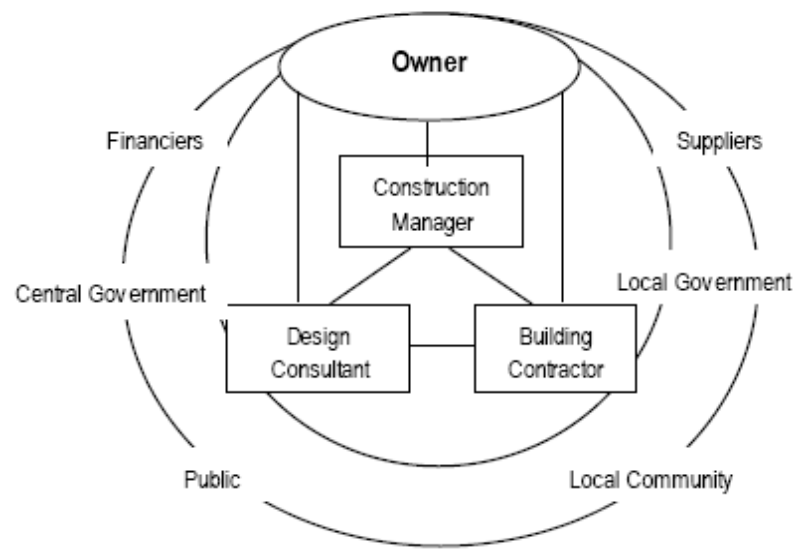

Fig. 2. Parties involved in a construction project

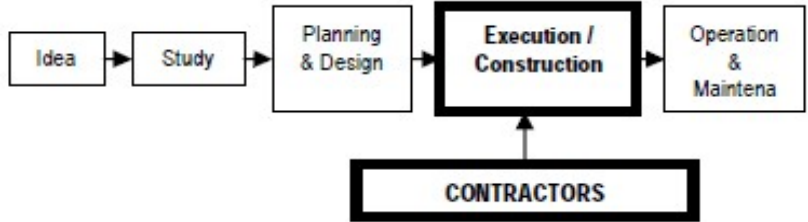

Fig. 3. Contractor involvement in the project development stages

Contractor involvement in the implementation of construction activities is in the course of development. According to the stages of implementation of the projects, the contractor gait can be described as in the following Fig. 3 [5]. In this period of time that contractors require the full support of foremen, subcontractors, suppliers to finish the job with quality, time and cost has been determined.

Supply chain system in a construction project is involving the suppliers of goods and services suppliers. Planning consultants and construction management consultants charged with overseeing the implementation of the development are supplier of services to the owner. Meanwhile, building contractors are often considered as a supplier of services and suppliers of goods as well, because they gave the service to build and also gave the building itself to the owner. However, in reality most contractors submit their work to the subcontractors. The most interesting is that the sub-contractor and the contractor can not carry out their work without assisted by mandor.

Supply chain system of construction project activities is indicated in the following picture Fig. 4. For one type of material supplier, actually consists of several suppliers. Likewise for sub-contractors, consist of several kind of sub-contractor such as sub-contractors of the land clearing, buildings, landscaping, roads, channel and others. Thus, when depicted as a whole, there will be more parties involved in the supply chain in construction industry.

Managing the supply chain is very important to achieve excellence in the quality of contractor activities [6]. It means that managing mandor is also quite important in order to get competitive advantage for contractor.

\section{B. Mandor and Foreman}

The mandor is part of project team, either in the sub contractor or in the main contractor. He has to be able to manage worker and also has technical responsibilities. The mandor is a person who also has capability to hire people to work together for a certain time, certain location and certain purpose at construction project. Mandor also has function as trainer, leader of that group of worker or unskilled worker, and he will be responsible for paying the worker base on their working hours. Data from the Ministry of Public Works Indonesia stating the amount of labor in the construction sector in 2009 reached 5.2 million people $(4.71 \%$ of the national workforce). Based on that number, $8 \%$ classified as experts, $30 \%$ classified as skilled labors, and the rest classified as unskilled labors [7]. Skills can be defined as the ability to perform the task well or better than average. Skills can also be described as the ability to translate knowledge into action [8]. 


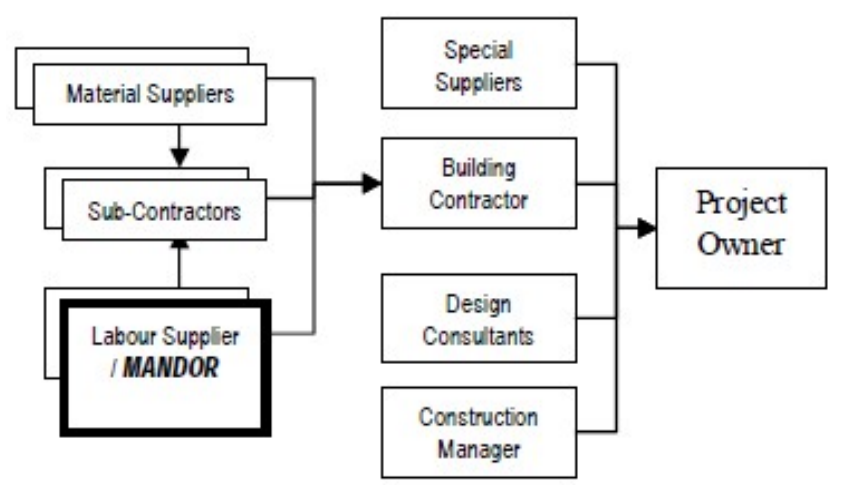

Fig. 4. Supply chain system in construction industry

There are many kind of mandor with different kind of job. There are steel mandor for steel working, wood mandor for wood working, dig mandor for digging work, foundation mandor, paint mandor and many others. Almost every single item of work breakdown structure has certain mandor. Mandor can be hired directly by project owner, main building contractor, or sub-contractor. Mandor can be anywhere in the construction activities. The individual labor, worker or even helper never been hired directly by any parties involved in the construction project. They are always hired by mandor, and then mandor is hired by those parties. In this situation, the interdependency to mandor is significant, in other word, mandor has an important role in the construction industry.

In other country, we recognize foreman which has similar position with mandor. The foreman is a construction worker with many years of experience in a particular trade who is charged with organizing the overall construction of a particular project. Typically the foreman is a person with specialist knowledge of a given trade who has moved into the position and is now focused on an overall management of all trades rather than any particular specialized group. Specifically, a foreman may train employees under his or her supervision, ensure appropriate use of equipment by employees, communicate progress on the project to a supervisor and maintain the employee schedule. Foremen may also arrange for materials to be at the construction site and evaluate plans for each construction job. The fact is, that every working environment has its own culture, which requires a special management style to be effective. Culture and leadership practice cannot be separated [9].

The difference between Foreman and mandor is located on the kind of work done by each. Foreman is naturally more structural than the mandor. The mandor has greater freedom in performing their duties. He is able to recruit his crew from workers to helpers in number and wage levels that are determined by internal agreement among themselves. Technically, mandor has to have coordination and responsible to the project superintendent. However, in employment, foremen have discretionary authority to manage his subordinates, particularly in hiring and firing, setting and determining the number of workers wages. This kind of management authorities are not owned by the foreman. Meanwhile, the mandor was not given the task to choose the material, unlike the foreman. Selection of material is carried out by the project superintendent.
TABLE II: MANDOR AND FOREMAN

\begin{tabular}{|l|c|c|}
\hline \multicolumn{1}{|c|}{ Duties } & Mandor & Foreman \\
\hline Assign Jobs & $\mathrm{V}$ & $\mathrm{V}$ \\
\hline Schedule Employees & $\mathrm{V}$ & $\mathrm{V}$ \\
\hline Supervise Employees & $\mathrm{V}$ & $\mathrm{V}$ \\
\hline Perform Construction Duties & $\mathrm{V}$ & $\mathrm{V}$ \\
\hline Reporting & $\mathrm{V}$ & $\mathrm{V}$ \\
\hline Chooses Materials & & $\mathrm{V}$ \\
\hline Hiring worker & $\mathrm{V}$ & \\
\hline Train worker & $\mathrm{V}$ & \\
\hline Make a payment & $\mathrm{V}$ & \\
\hline
\end{tabular}

\section{Mandor and Succeeding Construction Project}

Seeing such a large role of mandor, then the mandor utilization more effectively will improve the performance of the contractor that led to the successful of a project. The linkage between contractor and mandor is very closely, mutual support and interdependence. To that end, improving the competitiveness of the contractor must be done through cooperation between the contractor and mandor. Forms of cooperation can be realized in the following forms:

1) In implementing similar project activities, the contractor should always involve a certain mandor continuously, so that the mandor can gain a lot of experience and so it will increase the ability of supervisors itself. The more work done by mandor, the more experienced mandor is, in the sense of having a high level of expertise.

2) Cooperation that has existed between the contractors with the mandor will create synergies for contractor's capacity building in working on the projects. The synergies are realized by the cohesiveness between the contractor and the mandor, as they often work together.

3) The Cooperation that exists between mandor and contractors, as well as a means for contractors to perform technical guidance during the work project. Contractors have the opportunity to train, guide and educate mandors so that the mandors have a better performance. Good performance of the mandor will make better performance of the contractor.

4) The building contractor can develop mandor's financial and managerial capacity through the father-son relationship system. For operational needs, mandor can get funds from the contractor, who is considered as though as his father. Over the time, the funds were returned to the contractor without interest.

\section{CONCLUSION}

The parties involved in construction development are covering a wide range of functions. There are a supplier of goods, services, and both. Integration of supply chain has become important because of competition among building contractor in the construction industry. Mandor has an important role, which is very demanded by contractor. Best mandor and best contractor can be synergizing to get a competitive advantage in the construction industry. The main strategy to be done is to maintain a sustainable and 
continuous cooperation between contractor and mandor as a solid team, so that they can keep an unbroken supply chain.

\section{REFERENCES}

[1] Indonesia Center Bureau of Statistics, 2012

[2] H. P. Adi and M. F. Ni'am, "Improving skill's strategies of Indonesian construction labors to have global competitiveness," International Journal of Civil and Structural Engineering, vol. 3, Issue 1, pp. 151, 2012.

[3] Global Competitiveness Report-World Economic Forum. [Online]. Available: www.wforum.org/issues/global-competitiveness

[4] Rahardjo and H. Agus, "Supply chain system and management in real estate business for achieving competitiveness," (Sistem dan Manajemen Rantai Pasok pada Bisnis Pengembang Permukiman untuk mencapai Keunggulan Mutu). in Proc. National Seminar and Workshop of Modeling and Design System, Universitas Katolik Parahyangan, Bandung, pp.207.

[5] F. K. Pinto, Project Management, 2nd ed, Prentice Hall, 2009.

[6] J. R. Evans, and W. M. Lindsay, Managing for Quality and Performance Excellence, 8th ed, South-Western Cengage Learning, 2010.

[7] Nursyirwan, Iwan, Indonesian Construction Workers need Recognition (Tenaga Kerja Konstruksi Indonesia Perlu Pengakuan), Bulletin BPKSDM, Ministry of Public Works Indonesia, 2006.

[8] K. T. Odusami, "Perception of professionals concerning important skills of effective project leader," Journal of Management in Engineering, vol. 18, no. 2, pp. 61-67, 2002.
[9] S. B. Yisa, G. D. Holt, and M. Zakeri, "Factors affecting management motivation in the Iranian construction industry: A survey of site managers," in Proc. 16th Annual ARCOM Conference, Akintoye, A Ed, Association of Researchers in Construction Management, Glasgow Caledonian University, vol. 2, pp. 465-72, 6-8 September 2000.

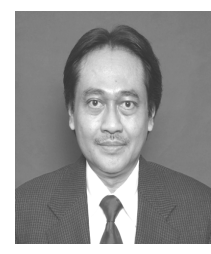

Hary Agus Rahardjo was born in Tegal, Indonesia in 1959. He got his $\mathrm{Ph} . \mathrm{D}$. degree in civil engineering from Colorado State University, USA in 2002.His research area is about Construction and Infrastructure Project Management.

Dr. Rahardjo has publication in Procedia-Social and Behavioral Sciences and in International Journal of Business and Management Studies.

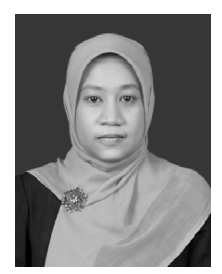

Henni Bermawi was born in Bandar Lampung, Indonesia, in March 1974. She received her Masters degree in Industrial Engineering from Institute of technology Bandung, Indonesia in 2003. Her research area is about Modeling System and Techno Economic.

Ms. Bermawi, has publication in Policy Study of Production Development of Ethanol as An Alternative Energy Source in The Transportation Sector With Dynamic System. 